\title{
THERMAL DEGRADATION OF WASTE POLYOLEFINES AND THEIR APPLICATION IN BLAST-FURNACE PROCESS
}

\section{INTRODUCTION}

In the market of plastics the main role is played by polyolefines, which determine about $60 \%$ the world production and consumption of polymer materials. Due to their physiological neutrality and physical and chemical properties they are called "polymers of the future". They have very good mechanical properties along with low density. Polyolefines are used for packaging, and in agriculture, horticulture, building industry, and electronics. Each year a sizeable amount of generated plastic wastes are landfilled. This method of waste disposal seems to be the worst from economical and environmental point of view. The main arguments against landfilling are: transport costs, landfill charges, space for landfilling and emitted decomposition gases: $\mathrm{CO}_{2}$ and $\mathrm{CH}_{4}$, which cause greenhouse effect. Plastic wastes have high calorific value and are suitable for co-processing with coal in power stations. Because of chemical composition of polyolefines they may be used as supplemental fuel in the blast furnace processes, thus simultaneously improving combustion efficiency.

The share of various polyolefine grades in world-wide sales (2000) is as follows [1]:

- PE-HD (High Density Polyethylene) - 27\%,

- PE-LD (Low Density Polyethylene) - $15 \%$,

- PE-LLD (Linear Low Density Polyethylene) - 15\%,

- PP (Polypropylene) - 38\%,

- other polyolefines $-5 \%$.

Almost $50 \%$ of total world's demand for low density polyethylene (PE-LD) is used for foil production. The foil is used to manufacture packaging for foods, medicines, medical products and films for agriculture and gardening. Moreover, PE-LD is widely used in building industry for construction and insulating foils.

* M.Sc., ** Ph.D.: Faculty of Metals Engineering and Industrial Computer Science, AGH University of Science and Technology, Krakow, Poland; mgeborek@metal.agh.edu.pl 
High density polyethylene (PE-HD) offers higher strength and higher thermal resistance, and it is harder than low density polyethylene. It is used to manufacture containers, packaging for chemicals, water and sewage tubes (high chemical resistance), carrier bags, foils, and packaging for cosmetics and foods.

Due to its high rigidity and durability, polypropylene (PP) is a perfect material for container production (e.g. cans, barrels). It is widely used as a structural material in the production of machinery housings, carrying boxes, tubes for potable water and sewage systems, containers for chemicals (due to high chemical resistance), fabrics, fishing nets, woven bags, strings (due to high elongation). Polypropylene high melting temperature (approximately $160^{\circ} \mathrm{C}$ ) and high transparency allow to manufacture PP bottles and fill them hot. PP packaging is very competitive as compared to other materials available on the market. It is an excellent barrier for moisture and odours.

Due to physical and chemical similarities of polymer materials from polyolefine group, there were efforts made to examine their destruction process. Similar course of waste material decomposition process for wastes selected from few economy fields would allow their simultaneous utilisation and selection of homogeneous parameters in their thermal decomposition process in power industry and metallurgical industry (in blast-furnace process).

At first turn the samples were put to elementary analysis. In order to examine the progress of thermal degradation process in atmospheric air, selected polyolefine group was subjected to thermal analysis (thermogravimetric analysis and differential scanning calorimetry).

\section{APPLICATION IN METALLURGICAL INDUSTRY}

As the group constituting considerable majority among all plastics, polyolefines possess highest heating values (approximately $40 \mathrm{MJ} / \mathrm{kg}$ ). Moreover, their chemical constitution, based mainly on carbon and hydrogen (Tab. 1), allows to use them in blast-furnace process as a substitute for coke.

Usage in the blast furnace process, in which pig iron is manufactured, may become one of the methods for managing polyolefine wastes. In Poland, currently there are 6 iron blast furnaces working, of total nominal production capacity approximately 6600 thousand $\mathrm{Mg} /$ year. Apart from iron ores and fluxes, also coke needs to be inserted in iron blast furnaces, working both as fuel and iron oxide reducer. So far, plastic wastes are not utilized in metallurgical processes in Poland.

In recent years, plastics have become additives successfully applied into the blast-furnace process in Germany (Stahlwerke Bremen and Krupp Hoesch) and Japan (NKK), amounting to $35 \mathrm{~kg} / \mathrm{Mg}$ of pig iron. Crushed wastes (obtained from municipal refuse) are inserted via nozzles into iron blast furnace, where they are gasified to $\mathrm{CO}$ and $\mathrm{H}_{2}$. Hydrogen produced in the decomposition process with $\mathrm{CO}$, is an iron oxide reducer. When coke and plastics are used, the reduction reactions for iron oxides are as follows:

- coke, pulverized coal

$$
\mathrm{Fe}_{2} \mathrm{O}_{3}+3 \mathrm{CO} \rightarrow 2 \mathrm{Fe}+3 \mathrm{CO}_{2}
$$

- plastics

$$
\mathrm{Fe}_{2} \mathrm{O}_{3}+2 \mathrm{CO}+\mathrm{H}_{2} \rightarrow 2 \mathrm{Fe}+2 \mathrm{CO}_{2}+\mathrm{H}_{2} \mathrm{O}
$$


We easily observe that when plastic is used as a reducer, the volume of generated $\mathrm{CO}_{2}$ drops by $1 / 3$.

The use of plastic wastes in world metallurgy, waste preparation, methods applied to proportion them into iron blast furnace, and economical advantages resulting from their use in the blast-furnace process are discussed in the following works: [2-7].

\section{EXPERIMENTAL}

\section{Samples}

Seven polyolefine samples were put to tests: two from household (cleaning material packaging) containing PE-HD and PP, the other five were from agricultural-gardening sector (these were polyethylene films: fertilizer bags and 2- and 4-season [new] and 4- and 5-season [used] gardening films).

Analysis results obtained for examined materials (Tab. 1) show very similar chemical constitution. During further tests, the samples were put to more analyses aimed to check the decomposition process progress.

Table 1. Plastic wastes analysis

\begin{tabular}{||l|c|c|c|c||}
\hline \multicolumn{1}{|c|}{ Chemical analysis } & PE-HD & PP & $\begin{array}{c}\text { PE-LD } \\
\text { gardening foil } \\
\text { (4-season, used) }\end{array}$ & $\begin{array}{c}\text { PE-LD } \\
\text { (fertilizer bag) }\end{array}$ \\
\hline Elementary analysis (wt. \%): & 15.10 & 15.26 & 14.93 & 15.48 \\
Hydrogen & 83.00 & 83.10 & 82.80 & 83.20 \\
Carbon & 0.10 & 0.03 & 0.07 & 0.05 \\
Sulphur & 1.21 & 1.46 & 1.93 & 1.27 \\
Nitrogen & 0.7 & 0.06 & 0.01 & 0.03 \\
\hline Ash (wt. \%) & 42.78 & 43.34 & 42.23 & 43.10 \\
\hline Heating value $(\mathrm{MJ} / \mathrm{kg})$ & & &
\end{tabular}

\section{Thermogravimetric Analysis (TG)}

In order to check the decomposition process progress for polyolefine materials (mass decrement rate in time), the samples were heated at the rate of 10 degrees/minute, at airflow $5 \mathrm{dm}^{3} / \mathrm{h}$, up to the temperature of $1000^{\circ} \mathrm{C}$. Mass of samples taken for tests was approximately $2 \mathrm{mg}$.

\section{Differential scanning calorimetry (DSC)}

The DSC measurements were carried out using a Netzsch DSC 200 differential scanning calorimeter, within temperature range $30-200^{\circ} \mathrm{C}$, at heating rate 10 degrees $/ \mathrm{min}$., in argon atmosphere. Mass of sample taken for tests was approximately $4 \mathrm{mg}$.

The DSC method allowed to determine melting temperatures, fusion heat, and to compute crystallinity degree for individual samples [9]. 


\section{RESULTS AND DISCUSSION}

TG curves for tested samples are shown on Figures 1 and 2. Decomposition curves are very much the same. Thermal decomposition begins at the temperature of approximately $250^{\circ} \mathrm{C}$, and stops at ca. $550^{\circ} \mathrm{C}$, with the exception of the polypropylene decomposition end temperature, which is approximately $400^{\circ} \mathrm{C}$. It is also very important that the combustion residue is very small (near zero).

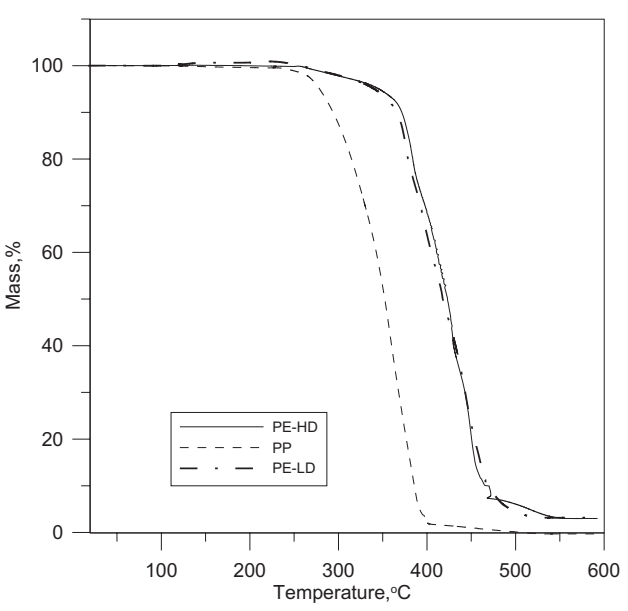

Fig. 1. TG curves for PE-HD, PP, PE-LD

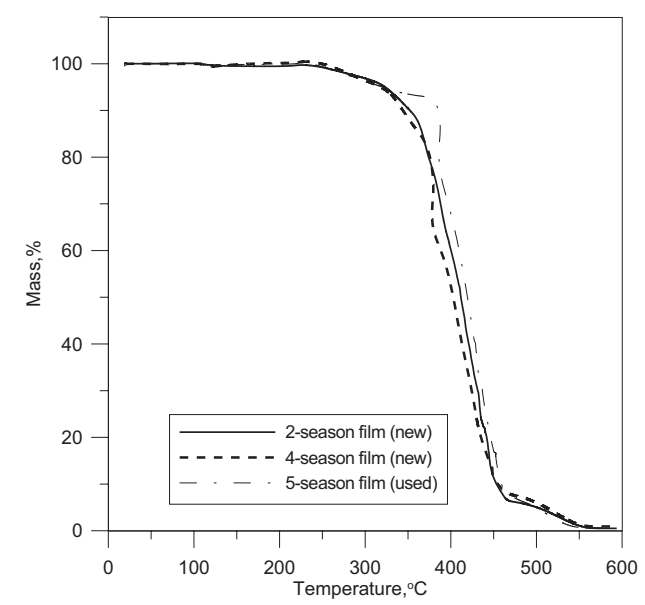

Fig. 2. TG curves for agricultural PE-LD films

The DSC curves for examined polymer materials are shown on Figures 3-6. Obtained results (Tab. 2) indicate that enthalpy change $\Delta H$ (fusion heat, computed using endothermic peak surface area) is definitely highest for sample containing PE-HD, and is $153.9 \mathrm{~J} / \mathrm{g}$.

Table 2. Results of the DSC analysis for polyolefine samples

\begin{tabular}{|l|c|c|c|c|c|c||}
\hline \multirow{2}{*}{ Sample } & $\Delta H$ & $T_{m}$ & $T_{\text {onset }}$ & $T_{\text {end }}$ & $\Delta H_{o}$ & $W_{k}$ \\
\cline { 2 - 7 } & $\mathrm{J} / \mathrm{g}$ & ${ }^{\circ} \mathrm{C}$ & ${ }^{\circ} \mathrm{C}$ & ${ }^{\circ} \mathrm{C}$ & $\mathrm{J} / \mathrm{g}$ & $\%$ \\
\hline PE-HD & 153.9 & 134.2 & 108.0 & 147.3 & 294 & 52 \\
\hline PE-LD & 74.12 & 119.9 & 54.8 & 129.7 & 294 & 25 \\
\hline PP & 67.71 & 144.4 & 95.6 & 160.8 & 207 & 33 \\
\hline $\begin{array}{l}\text { 2-season PE-LD } \\
\text { film (new) }\end{array}$ & 64.66 & 108.5 & 62.5 & 127.4 & 294 & 22 \\
\hline $\begin{array}{l}\text { 4-season PE-LD } \\
\text { film (new) }\end{array}$ & 79.41 & 108.7 & 59.1 & 127.3 & 294 & 27 \\
\hline $\begin{array}{l}\text { 4-season PE-LD } \\
\text { film (used) }\end{array}$ & 84.78 & 110.7 & 62.8 & 117.9 & 294 & 29 \\
\hline $\begin{array}{l}\text { 5-season PE-LD } \\
\text { film (used) }\end{array}$ & 73.63 & 111.0 & 67.8 & 127.3 & 294 & 25 \\
\hline
\end{tabular}




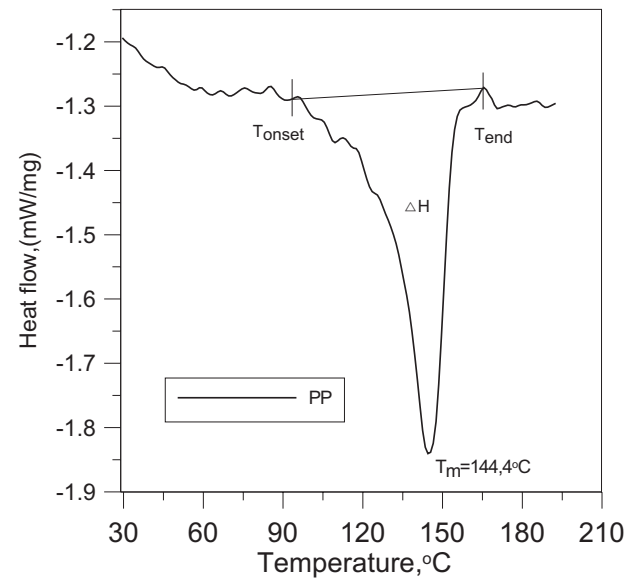

Fig. 3. DSC curve for used PP

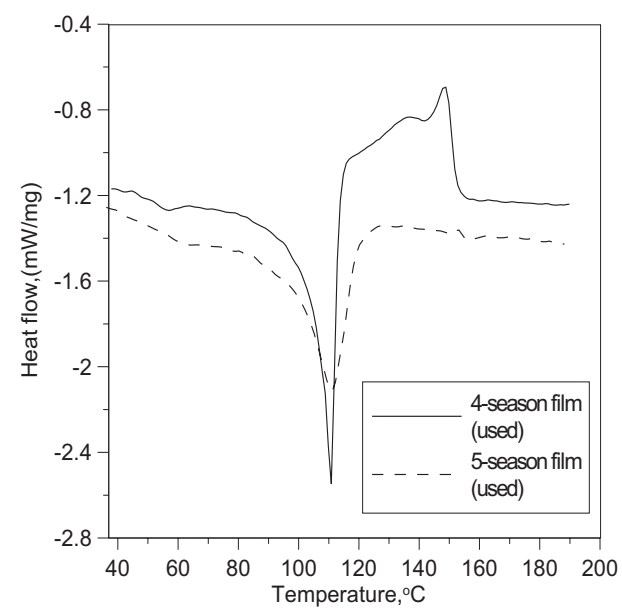

Fig. 5. DSC curves for used agricultural PE-LD films

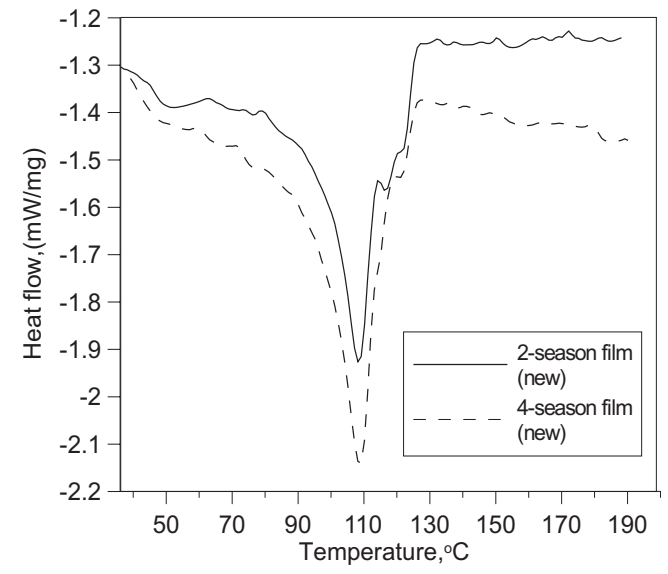

Fig. 4. DSC curves for non-used agricultural PE-LD films

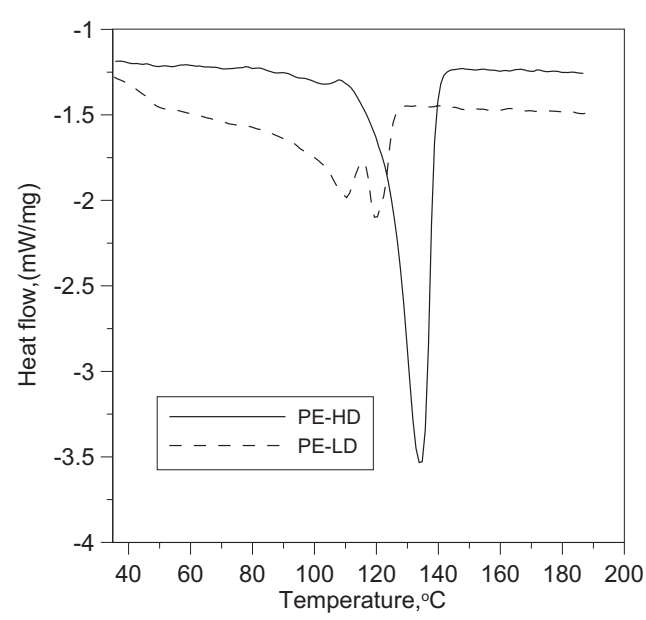

Fig. 6. DSC curves for used PE-HD and PE-LD

Moreover, melting process initial $\left(T_{\text {onset }}\right)$ and final $\left(T_{\text {end }}\right)$ temperature values were determined for each of the tested samples. The temperature, in which melting process ran fastest, was marked $T_{m}$ (peak top). Figure 6 shows high differences between PE-HD and PE-LD peak surface area. This proves considerable difference between PE-HD and PE-LD fusion heat values, which is due to varying structure of macromolecules. PE-HD has linear structure with small fraction of short branches and no long branches, as a result of which chains are close-packed. PE-LD has branched structure with considerable fraction of long 
and branched lateral chains. Melting peak surface area is proportional to its crystalline phase content in a sample. Crystallinity degree

$$
W_{k}=\frac{\Delta H}{\Delta H_{o}}
$$

was computed as a ratio of tested sample fusion heat $(\Delta H)$ and theoretical melting enthalpy of entirely crystalline sample $\left(\Delta H_{o}\right)$ [10]. For example, crystallinity degree $W_{k}$ for PE-HD is $52 \%$, and for PE-LD $-25 \%$.

\section{CONCLUSION}

Partial replacement of iron blast furnace coke with waste plastics allows to reduce primary fuel consumption, and thus to lower pig iron production costs. So far, only plastics recovered from municipal refuse have been used as substitute fuel in the blast-furnace process.

The TG analysis results show very similar progress of decomposition process, which ends at the temperature of approximately $550^{\circ} \mathrm{C}$, with the exception of PP $\left(400^{\circ} \mathrm{C}\right)$. Thermal decomposition for samples begins at approximately $250^{\circ} \mathrm{C}$. Very close melting point (ca. $110^{\circ} \mathrm{C}$ ) and fusion heat (approximately $70 \mathrm{~J} / \mathrm{g}$ ) is observed for polyethylene foils. Obvious difference of PE-HD melting point $\left(134^{\circ} \mathrm{C}\right)$ and fusion heat $(154 \mathrm{~J} / \mathrm{g})$, as compared to other polyethylene samples results from morphological structure and high crystalline phase fraction $(52 \%)$. Also, PP melting point $\left(144^{\circ} \mathrm{C}\right)$ is much higher than in case of other materials.

Obtained test results allow to state that polyolefine wastes both from households and from agriculture and gardening industries have very similar chemical constitution, and course of waste material decomposition process is sufficiently close to use them as a homogeneous group of fuels. It is very important from point of view of production scope in Poland, where greenhouse system is not so well-developed, as e.g. in Southern Spain, therefore when one wishes to ensure permanent reserves of fuel derived from plastics, it is necessary to take into account the need to mix them with plastics coming from other sources.

Additionally, carbon content in tested materials $(83.1-86 \%)$ is very close to its content in power coal (ca. $82 \%$ ), whereas sulphur content in plastics $(0.03-0.10 \%)$ is much lower than in power coal (ca. $0.4-1.0 \%$ ), which considerably affects $\mathrm{SO}_{\mathrm{x}}$ emission. Moreover, ash content in tested polyolefine plastics $(0.01-0.7 \%)$ is definitely lower than for power coal (4-20\%), as a result of which the problem involving utilization of ashes from plastics combustion is practically non-existent.

\section{Acknowledgements}

Polish Ministry of Science and Higher Education sponsors this work (Grant No. 3 T10B 008 29). 


\section{REFERENCES}

[1] Czaja K.: Poliolefiny, WNT, Warszawa 2005, p. 15

[2] Leszczyński S., Gęborek M.: Utylizacja odpadów termoplastycznych i termoutwardzalnych w przemyśle metalurgicznym. „Odpady 2004' : teoretyczne i praktyczne problemy zagospodarowania odpadów hutniczych: VI Międzynarodowa Konferencja Naukowa, Kraków 27-29 maja 2004, (Ed.) J. Nowakowski; Fundacja Metale Nieżelazne „Tradycja i Rozwój” [etc.]. — [Kraków : FMN „Tradycja i Rozwój”], 2004, pp. $42-52$

[3] Furukawa T.: Plastic as ironmaking fuel at NKK. New Steel, 5 (1998)

[4] Ogaki Y., Tomioka K., Watanabe A., Arita K., Kuriyama I., Sugayoshi T.: Recycling of Waste Plastic Packaging in a Blast Furnace System. NKK Technical Review, 84 (2001)

[5] Burgert P.: A substitute for oil: plastic. New Steel, 11 (1996)

[6] Hotta H.: Recycling Technologies for Promoting Recycling-oriented Society. NKK Technical Review, 88 (2003)

[7] Campbell P. E., McCahey S., Williams B. C., Beekes M. L.: Coal and plastic waste in PF boiler. Energy Policy, 28 (2000)

[8] Mark F. E., Rodriguez J.: Energy Recovery of Greenhouse PE Film: Co-combustion in a coal fired power plant. Technical Report from: Association of Plastics Manufacturers in Europe, Brussels, 1999

[9] Hatakeyama T., Quinn F. X.: Thermal Analysis - Fundamentals and Applications to Polymer Science. Wiley and Sons, Chichester, 1999, p. 32

[10] http://athas.prz.rzeszow.pl

Received

December 2006 
